\title{
Rola krzyża w zbawczym dziele Boga w teologii św. Pawła
}

Św. Paweł pisał swe listy jako świadek Chrystusa ukrzyżowanego i uwielbionego, wykazując w nich, że jest On oczekiwanym od wieków i zapowiadanym przez proroków Mesjaszem, który dokonał zbawienia przez wydanie siebie w ofierze, śmierć na krzyżu i zmartwychwstanie (por. Ga 1, 4; 2, 20). Ze względu na doniosłość tych prawd zbawczych ewangelia głoszona przez apostoła narodów ,została zdominowana przez Ewangelię krzyża i zmartwychwstania"'. Szczegółowe omówienie całej soteriologii św. Pawła wymagałoby bardzo obszernego opracowania. Z tej przyczyny w tym artykule chcemy jedynie dokonać głębszej analizy kilku tekstów, w których Apostoł pisze na temat ofiary krzyżowej Chrystusa i jej roli w zbawczym dziele.

Chrystus ukrzyżowany wyrazem

miłości, mocy i mądrości Bożej

W 1 Kor 15, 3-8 św. Paweł przekazuje credo Kościoła pierwotnego, zgodnie z którym istotą ziemskiego posłannictwa Chrystusa było wypełnienie Pism, wydanie siebie na śmierć krzyżową ,za nasze grzechy”, zmartwychwstanie i ukazanie się swym uczniom. W Ga 2, 20 natomiast wyznaje, iż jego obecne życie jest życiem wiary w Tego, który umiłował go i samego siebie wydał za niego (podobnie teżjest w Ef 5, 2). Gdy roz-

${ }^{1}$ H. Witczyk, Pawłowa ewangelia o Chrystusie Panu odejściem od Jezusowej ewangelii o królestwie Bożym?, [w:] Orędzie Pawłowe - aktualne jeszcze dzisiaj? Poznać, aby iść śladem nauki, sposobu życia, red. M. Bednarz, P. Łabuda, Tarnów 2009, s. 83. 
poznał, że prześladowany przez niego Jezus jest Synem Bożym oraz że również jego otacza swą miłością, odtąd dalsze swe życie oddał na służbę swemu Zbawicielowi i Panu'2. Co więcej, wewnętrznie czuł się zespolony z Chrystusem ukrzyżowanym (por. Ga 2, 19) i usiłował naśladować Go duchowo, pozwalając Mu, by w nim i przez niego objawiał światu miłość Boga ${ }^{3}$. W Ga 2, 19-20 Paweł przedstawia też miłość Chrystusa jako istotną cechę Jego natury, używając zaś imiesłowu w aoryście: agapessantos („ten, który umiłował”), sugeruje, że ta miłość wyraziła się w konkretnym, historycznym wydaniu siebie w ofierze. Czynem tym Zbawiciel przeciwstawił się ciążącemu na ludzkości prawu grzechu i zniszczył jego moc. Ponieważ grzech ze swej istoty jest dobrowolnym oddaniem się złym żądzom, Chrystus z miłości oddał się na śmierć, by wyzwolić człowieka spod tej władzy kierującej go ku śmierci wiecznej4.

Myśl tę apostoł narodów jeszcze bardziej pogłębia w Liście do Rzymian, gdzie wyraźnie stwierdza: „Bóg zaś okazuje nam swoją miłość przez to, że Chrystus umarł za nas, gdyśmy byli jeszcze grzesznikami” (Rz 5, 8). Jedynym motywem ofiary zbawczej, którą z woli Ojca złożył z siebie Syn Boży, jest miłość, której bezmiaru nie jest w stanie pojąć umysł ludzki. Jeżeli bowiem nawet ofiarowanie swego życia za przyjaciela oznacza heroizm i doskonałą miłość (por. Rz 5, 7; J 15, 13), to śmierć za grzesznika i bezbożnika wyraża taką miłość, do jakiej jest zdolny tylko Bóg. Wyraża się ona w tym, że Stwórca zawsze pragnie dobra swego stworzenia, a ponieważ ono buntuje się przeciwko Niemu (zob. Rz 1, 21-2, 24), On sam bez żadnych zasług człowieka wychodzi z inicjatywą zbawczą, a Jego miłość jest tak wielka, że „nawet własnego Syna nie oszczędził, ale Go za nas wszystkich wydał" $(\mathrm{Rz} 8,32)^{5}$. Z czysto ludzkiego punktu widzenia można wręcz powiedzieć, że w krzyżu Bóg objawia miłość całkowicie paradoksalną i nielogiczną ${ }^{6}$, miłość, której nie może zgasić żadne przestępstwo człowieka. Z lektury najstarszych tradycji starote-

${ }^{2}$ Por. J. Rohde, Der Brief des Paulus an die Galater, Berlin 1989, s. 117.

${ }^{3}$ E. de Witt Burton, A Critical and Exegetical Commentary on the Epistle to the Galatians, Edinburgh 1988, s. 136.

${ }^{4}$ Por. K. Romaniuk, Soteriologia św. Pawła, Warszawa 1983, s. 94.

${ }^{5}$ Por. J. Harasim, Ewangelia św. Pawła, „Studia Teologiczne” 4 (1986), s. 11.

${ }^{6}$ Por. A. Pitta, Lettera ai Romani. Nuova versione, introduzione e commento, Milano $2001^{2}$, s. 225. 
stamentowych można wyciągnąć wniosek, że krzyż nie był zamysłem Boga od początku. Jego zamiarem było, by ludzkość przyjęła Mesjasza i Jego naukę. Kiedy jednak przewidział Jego odrzucenie, wówczas Jego cierpienie i śmierć na krzyżu uczynił narzędziem zwycięstwa nad złem. Tym sposobem też krzyż stał się punktem kulminacyjnym objawienia się Boga w Jego Synu, bez krzyża bowiem nie poznalibyśmy ogromu Bożej miłości względem nas. Z tej właśnie przyczyny krzyż jest najbardziej wymownym dowodem i probierzem tego, że Bóg ze swej natury jest miłością7 (co na swój sposób uzasadnia też $1 \mathrm{~J}$ 4, 10-11. 16).

Kontemplując to objawienie niepojętej miłości Boga w ofierze Jego Syna, św. Paweł oświadcza zdecydowanie w Ga 6, 14, przeciwstawiając się tym, którzy zmuszali chrześcijan do obrzezania: „Co do mnie, nie daj Boże, bym się miał chlubić z czego innego, jak tylko z krzyża Pana naszego Jezusa Chrystusa". Także w kilku innych miejscach swych listów uświadamia swym adresatom, że nikt nie ma żadnych podstaw ku temu, by się chełpić z powodu swej godności lub własnych czynów (zob. 1 Kor 1, 27-29; 4, 7; Ef 2, 9), leczjedyną przyczyną chluby wierzących jest Bóg i otrzymane od Niego dary łaski (zob. Rz 5, 2. 11; 1 Kor 1, 31; Flp 3, 3). Czytając jednak to zdanie z Ga 6, 14, należy być świadomym tego, że dla człowieka starożytnego chlubienie się krzyżem było czymś absurdalnym i pozbawionym rozsądku. W starożytności krzyż był okrutnym i wymyślnym narzędziem śmierci dla kryminalistów i buntowników podłego urodzenia (barbarzyńców i niewolników) ${ }^{8}$. Przy stosowaniu tej kary chodziło nie tylko o śmierć powolną i bolesną, ale też poniżającą. Śmierć na krzyżu oznaczała fizyczne i społeczne wykluczenie z życia, czego wyrazem był bardzo rygorystyczny przepis, zgodnie z którym ukrzyżowanemu nie przysługiwało godziwe pogrzebanie, a jeśli nawet w wyjątkowych okolicznościach udzielano mu tej łaski, to mógł być zło-

${ }^{7}$ Por. C. E. B. Cranfield, A Critical and Exegetical Commentary on the Epistle to the Romans, Edinburgh-New York 2001, s. 265; W. Rakocy, Boża sprawiedliwość objawiająca się w dziele zbawienia człowieka przez krzyż, „Verbum Vitae” 1 (2002), s. 159-160.

${ }^{8}$ Szerzej na temat podejścia starożytnych ludzi do krzyża zob. M. Hengel, Mors turpissima crucis. Die Kreuzigung in der antiken Welt und die „Torheit“ des „Wortes vom Kreuz", [w:] Rechtfertigung. Festschrift für Ernst Käsemann zum 70. Geburtstag, hrsg. von J. Friedrich [i in.], Tübingen-Göttingen 1976, s. 125-184; H. Merklein, Das paulinische Paradox des Kreuzes, [w:] tenże, Studien zu Jesus und Paulus, t. 2, Tübingen 1998, s. 286-288; D. W. Chapman, Ancient Jewish and Christian Perceptions of Crucifixion, Grand Rapids 2010. 
żony jedynie w grobie bezimiennym. Apostoł narodów znał ten gorszący aspekt krzyża jako narzędzia najbardziej haniebnej śmierci przeznaczonej dla największych złoczyńców. Pisząc do Koryntian, przyznaje, że Chrystus ukrzyżowany ,jest zgorszeniem dla Żydów, a głupstwem dla pogan" (1 Kor 1, 23). Z powodu odrażającego charakteru krzyżowania skazańców prawo żydowskie nie przewidywało tej kary. Jeśli zaś chodzi o świat pogański, jego podejście do krzyża najlepiej wyraża wypowiedź Cycerona z 63 roku przed Chrystusem zawarta W obronie C. Rabiriusa: „Sam wyraz «krzyż» powinien być daleko nie tylko od ciała obywatela rzymskiego, ale także od jego myśli, oczu i uszu. Bo nie tylko stosowanie tej kary śmierci, ale nawet napomknienie o niej niegodne jest obywatela rzymskiego i człowieka wolnego"'.

Mimo tak gorszącego charakteru krzyża i choćJezus, gdy został zawieszony na krzyżu, był przedmiotem wielu dotkliwych kpin i wyszydzenia przez swych rodaków (por. Mt 27,39-44 i par.), św. Paweł zdecydowanie oświadcza, iż jego głównym zadaniem jest głoszenie krzyża (por. 1 Kor 1, 17-18), a nawet z wielką dumą przyznaje się do Chrystusa ukrzyżowanego, wie bowiem, że w gruncie rzeczy On sam zechciał uniżyć siebie i ogołocić z należnej Mu chwały Bożej, a następnie został przez Ojca wywyższony „nad wszystko”, co elokwentnie opiewa starochrześcijański hymn zacytowany w Flp 2, 6-11. Co więcej, właśnie ofiara na krzyżu i zmartwychwstanie przyniosły ludzkości życie nowe, wolne od przekleństwa, które na świat ściągnął grzech (por. Ga 3, 13), oraz wyzwolone spod władzy grzechu i śmierci wiecznej (por. Ga 2, 19-20) ${ }^{10}$.

W 1 Kor 1, 18 apostoł narodów oświadcza, iż głoszona przez niego nauka o krzyżu „głupstwem jest dla tych, co idą na zatracenie, mocą Bożą zaś dla nas, którzy dostępujemy zbawienia", a kilka wersetów dalej dodaje, że Chrystus ukrzyżowany jest „mocą Bożą i mądrością Bożą” (w. 24). W tekście tym usiłuje ukazać wzniosłość ofiary krzyżowej, przy czym w swych wywodach dostosowuje się do mentalności swych adresatów. W 1 Kor 1,17-25 przeciwstawia najpierw naukę krzyża (ho logos tou staurou) mądrości słowa (sofia logou). Wśród narodów starożytnych Grecy słynęli z umiłowania mądrości, które z biegiem czasu uzyskało

${ }^{9}$ Tekst polski za: W. Kopaliński, Słownik symboli, Warszawa $1991^{2}$, s. 175.

${ }^{10}$ Por. A. Vanhoye, Lettera ai Galati. Nuova versione, introduzione e commento, Milano 2000, s. 145. 
techniczną nazwę filozofii (fileō - „kocham”; sofia - „mądrość”, „wiedza”, ,nauka”). Uważali przy tym, że ludzki rozum jest w stanie wyjaśnić wszystkie tajemnice wszechświata, a nawet może być wyznacznikiem wszelkich norm moralnych i kryterium prawdy. Użyte przez Pawła wyrażenie „mądrość słowa” może oznaczać jakiś system myślowy, teorię o charakterze spekulatywnym bądźteż wykład błyskotliwy, który niekiedy był pusty i bez treści ${ }^{11}$. Kiedy św. Paweł ustosunkowuje się negatywnie do ludzkiej mądrości, nie sugeruje, że Bóg, dając człowiekowi rozum, zarazem nie pozwala na korzystanie z tego daru. Wskazuje raczej na to, że „,korzystanie z niego w zarozumiały, manipulacyjny i egoistyczny sposób sprzeciwia się zamiarom Bożym"12.

Tej właśnie mądrości ludzkiej Paweł przeciwstawia naukę o krzyżu Chrystusa, która jest wyrazem niepojętej dla człowieka mądrości Bożej. Już przez proroka Izajasza Bóg mówił: „,myśli moje nie są myślami waszymi ani wasze drogi moimi drogami" (Iz 55, 8). Do tej prawdy Paweł nawiązuje w Rz 11, 33-36, gdzie sławi głębokość „bogactw, mądrości i wiedzy Boga", jak też w 1 Kor 2, 7-8, gdzie z kolei pisze, że mądrość Boża jest dla ludzi tajemnicą, „której nie pojął żaden z władców tego świata; gdyby ją bowiem pojęli, nie ukrzyżowaliby Pana chwały". Ludzie odrzucili Bożą mądrość, okazując tym samym wrogość wobec samego Boga, a najbardziej drastycznym wyrazem takiej postawy było ukrzyżowanie Jezusa, który okazał się Panem chwały. Jednakże mądrość Boga polega na tym, że ten radykalny akt sprzeciwu wobec Jego Syna i Jego śmierć zdołał włączyć w swe plany zbawcze. Dzięki temu też Jego myśli i zamiary, które do tej pory tylko częściowo były objawiane przez proroków i wydarzenia historyczne, zostały najpełniej odsłonięte w nauczaniu, męce i śmierci Syna Bożego. Odtąd tylko ten może zgłębić tajemnice Bożego objawienia oraz zbawczych planów Bożych, kto jest otwarty na przyjęcie nauki o krzyżu i kto jest zdolny poznać w Chrystusie ukrzy-

${ }^{11}$ Por. J. Czerski, Słowo o krzyżu antytezą mądrości świata. Analiza lingwistyczno-egzegetyczna 1 Kor 1, 18-25, [w:] Haurietis de fontibus. Społeczno-etyczne kwestie wczoraj i dziś. Księga pamiątkowa dedykowana ks. doktorowi Piotrowi Kosmolowi, wykładowcy Wydziału Teologicznego Uniwersytetu Opolskiego, z okazji 40-lecia pracy dydaktycznej, red. P. Morciniec, Opole 2005, s. 20; tenże, Pierwszy List do Koryntian, Wrocław 2009, s. 139.

${ }^{12} \mathrm{~J}$. Załęski, Głupstwo krzyżajako wyraz mądrości Bożej a mądrość świata w 1 Kor 1 18-25, „Słowo Krzyża” 2 (2008), s. 102-103. 
żowanym Zbawiciela świata ${ }^{13}$. Jezus Chrystus zatem „stał się dla nas mądrością od Boga i sprawiedliwością, i uświęceniem, i odkupieniem" (1 Kor 1, 30), ponieważ w swej istocie jest wprowadzeniem w czyn woli Boga, który pragnie uczynić ludzi sprawiedliwymi i świętymi, czyli w pełni włączonymi w Jego dzieło zbawcze ${ }^{14}$.

Krzyż Chrystusa i Chrystus ukrzyżowany jest mądrością Bożą (por. 1 Kor 1, 18. 24), której nie da się zrozumieć i wytłumaczyć zwyczajną, ludzką logiką. Największy zaś paradoks polega na tym, że krzyż będący przedmiotem pogardy i narzędziem największego poniżenia stał się przyczyną wywyższenia Chrystusa do chwały Ojca (por. Flp 2, 8), przez co też ujawnił ukrytą w nim siłę. To, że właśnie w nim ujawnia się zbawcza moci mądrość, wynika tylko i wyłącznie stąd, iż sam Bóg w swej wolności uczynił Tego, który został odrzucony, Zbawicielem, a tych, którzy w swej niewierze Go odrzucili, doprowadza do wiary ${ }^{15}$. W krzyżu ujawnia się moc zbawcza nie dlatego, że jest on drzewem hańby, ale ponieważ w nim i przez niego działa sam Bóg, który wybrał go jako najbardziej wymowny znak swej miłości do grzesznego człowieka. Źródłem jego mocy jest zatem moc samego Boga i Jego Syna Jezusa Chrystusa ${ }^{16}$.

\section{Krzyż narzędziem wyzwolenia \\ z przekleństwa grzechu $(\mathrm{Ga} 3,13)$}

Jak zostało wyżej powiedziane, krzyż stał się istotnym narzędziem w zbawczym dziele Boga właśnie z powodu swego hańbiącego piętna. Św. Paweł dokonuje refleksji nad tą prawdą w Ga 3, 10-14, gdzie wcho-

${ }^{13}$ Por. C. Dotolo, La rivelazione cristiana. Parola, evento, mistero, Milano 2002, s. 72-73. Szerzej na ten temat zob. J. Triebel, Die im Geheimnis verborgene Weisheit Gottes: 1. Korinther 2, 7, „Theologische Beiträge“ 31 (2000), s. 225-228; M. Konradt, Die korinthische Weisheit und das Wort vom Kreuz. Erwägungen zur korinthischen Problemkonstellation und paulinischen Intention in 1 Kor 1-4, „Zeitschrift für die neutestamentliche Wissenschaft" 94 (2003), s. $181-214$.

${ }^{14}$ Tak tekst 1 Kor 1, 30 wyjaśnia J. Lévêque, Sagesse et dessin de Dieu, „Nouvelle Revue Théologique” 129 (2007), s. 201; zob. M. Rosik, Pierwszy List do Koryntian. Wstęp, przekład z oryginału Komentarz, Częstochowa 2009, s. 154 (Nowy Komentarz Biblijny, 7).

${ }^{15}$ Por. H.-C. Kammler, Kreuz und Weisheit: eine exegetische Untersuchung zu 1 Kor 1 , 10-3, 4, Tübingen 2003, s. 117.

${ }^{16}$ Zob. R. F. Collins, D. J. Harrington, First Corinthians, Collegeville 1999, s. 102. 
dzi w polemikę z Żydami, którzy podważali jego autorytet apostolski oraz wiarygodność głoszonej przez niego ewangelii, a także usiłowali nakłonić chrześcijan do przyjęcia obrzezania i przestrzegania Prawa Mojżeszowego ${ }^{17}$. Rabini żydowscy nauczali, że wystarczy literalnie wypełnić przepisy Prawa, by otrzymać nagrodę od Boga. Uważali tym samym, że zbawienie płynie z zachowania przykazań ${ }^{18}$. Sprzeciwiając się ich twierdzeniom, Paweł najpierw wskazuje na bardzo kruchy grunt ich przekonań. Przypomina mianowicie, że w Pwt 27, 26 jest zapis: „Przeklęty każdy, kto nie trzyma się wiernie nakazów tego Prawa i nie wypełnia ich" (Ga 3,10b). Godne uwagi jest to, że cytuje ten fragment, całkowicie zmieniając jego intencję. Zawarte w Pwt 28, 15-68 przekleństwa odnosiły się do tych, którzy nie wypełniali Prawa, i miały na celu zachęcić do wierności przykazaniom. Apostoł natomiast posługuje się tym tekstem w stosunku do tych, którzy spełniali uczynki zgodne z Prawem i innych do nich nakłaniali ${ }^{19}$, dając do zrozumienia, że nikt nie jest w stanie zachować wszystkich bez wyjątku przepisów Prawa. $Z$ takiego stanu rzeczy wyciąga wniosek, że „na tych wszystkich, którzy polegają na uczynkach Prawa, ciąży przekleństwo" (Ga 3,10a). Ci zatem, którzy pokładali nadzieję w Prawie i traktowali je jako źródło zbawienia, znaleźli się w stanie przekleństwa, w sytuacji bez nadziei na otrzymanie od Boga daru życia (por. Ga 3, 12). W gruncie rzeczy bowiem Prawo albo coś nakazywało, albo czegoś zabraniało, ale nie dawało żadnych uzdolnień do wypełniania stawianych przez nie wymagańn ${ }^{20}$.

Apostoł narodów nie krytykuje samego Prawa. Jest świadomy tego, że ono pochodzi od Boga i dlatego jest święte. Uznaje też, że wszystkie zawarte w nim przykazania są święte, sprawiedliwe i dobre (por. Rz 7, 12). Zdecydowanie jednak podważa przekonanie, że zbawienie można otrzymać przez samo wykonywanie uczynków zgodnych z Prawem. Wykazuje, że jedynym Zbawicielem jest Jezus Chrystus. On właśnie swą

${ }^{17}$ Szerzej na ten temat pisze W. Rakocy, Antypawłowa opozycja w Liście do Galatów, „Roczniki Teologiczno-Kanoniczne” 44 (1997) nr 1, s. 117-127.

${ }^{18}$ Podstawą takiego przekonania może być np. Kpł 18, 5, gdzie po nakazie: „Będziecie przestrzegać moich ustaw i moich wyroków” jest dodana obietnica: „Człowiek, który je wypełnia, żyje dzięki nim"; zob. J. Rohde, Der Briefdes Paulus an die Galater, dz. cyt., s. 141.

${ }^{19}$ Por. A. Vanhoye, Lettera ai Galati, dz. cyt., s. 84.

${ }^{20}$ Por. K. Romaniuk, Soteriologia św. Pawła, dz. cyt., s. 111. 
ofiarą na krzyżu przyniósł nadzieję tym, którzy się znaleźli w stanie przekleństwa ciążącego na ludzkości z powodu grzechu. W innym bowiem miejscu Księgi Powtórzonego Prawa jest orzeczenie: „Przeklęty przez Boga jest każdy, którego powieszono na drzewie” (Pwt 21, 23). Ściśle rzecz biorąc, tekst ten nie odnosi się do ukrzyżowania. Chodzi w nim o przestępcę, który zasługiwał na karę śmierci, został stracony, a następnie powieszony na drzewie w celu odstraszenia innych od popełniania podobnej zbrodni (zob. Pwt 21, 22). Paweł odwołuje się do tego tekstu tylko dlatego, że końcowy stan człowieka ukrzyżowanego oraz trupa zawieszonego na drzewie jest identyczny ${ }^{21}$. Cytuje jednak ten przepis prawny w nieco skróconej postaci: „Przeklęty jest każdy, którego powieszono na drzewie” (Ga 3,13c). Pomija słowa „przez Boga”, ponieważ nie da się ich odnieść do Chrystusa Jezusa. Syn Boży nie był przeklęty przez swego Ojca, lecz sam dobrowolnie wziął na siebie przekleństwo, zgadzając się na hańbiącą śmierć na drzewie krzyża. Paweł pisze dosłownie, że stał się „za nas przekleństwem” (hyper hēmōn katara - Ga $3,13 b)$, posługując się rzeczownikiem abstrakcyjnym "przekleństwo" (katara) w miejsce przymiotnika "przeklęty"22 w celu wzmocnienia idei. W tekście tym nie chodzi o to, że Jezus Chrystus jako jedyny sprawiedliwy odpowiada za grzechy grzeszników lub że można było znaleźć w Nim coś grzesznego i zasługującego na przekleństwo, ale o to, że On stanął jako nasz reprezentant, wziął na siebie hańbę krzyża „za nas”, czyli zajął "nasze miejsce”, dla "naszego dobra” przyjął na siebie stan grzesznej ludzkości zasługujący na potępienie ${ }^{23}$. Pisząc „za nas”, Paweł ponadto podkreśla, że ofiara Chrystusa ma charakter uniwersalny ${ }^{24}$. On umarł nie tylko za Żydów, na których ciążyło przekleństwo wypły-

${ }^{21}$ Por. A. Vanhoye, Lettera ai Galati, dz. cyt., s. 87.

${ }^{22}$ Naśladuje w tym autorów starotestamentowych, zwłaszcza Jr 24, 9; 49, 18 (LXX); Za 8, 13; por. F. Büchsel, Ara, kataraomai, katara, epikataratos, eparatos, [w:] Theologisches Wörterbuch zum Neuen Testament, begründet von G. Kittel, t. 1, Stuttgart 1957, s. 450.

${ }^{23}$ Por. H. Merklein, Das paulinische Paradox des Kreuzes, art. cyt., s. 293; S. Czyż, Chrystologiczne przesłanie Ewangelii Pawłowej, „Studia Paradyskie” 17-18 (2007-2008), s. 40; A. Paciorek, Znaczenie śmierci Jezusa w myśli św. Pawła, [w:] Orędzie Pawłowe-aktualne jeszcze dzisiaj, dz. cyt., s. 92-96.

${ }^{24}$ Obszerną refleksję na ten temat zawiera artykuł: T. L. Donaldson, The 'curse of the Law' and the inclusion of the Gentiles; Galatians 3, 13-14, "New Testament Studies" 32 (1986), s. 94-112. 
wające z nieprzestrzegania Prawa Mojżeszowego, ale za wszystkich grzeszników bez wyjątku.

Paweł oznajmia jako dobrą nowinę, że Chrystus, stając się za nas przekleństwem, „wykupił nas” z przekleństwa Prawa. Używa w tym miejscu czasownika eksagoradzō, który pochodzi z dziedziny handlowej i oznacza dosłownie „wykupić” (np. niewolnika z niewoli), uiszczając wyznaczoną przez sprzedawcę należność. Jak zauważył swego czasu S. Lyonnet, czasownik ten bardzo rzadko występuje w literaturze greckiej i wszędzie ma znaczenie czasownika prostego agoradzō, czyli „,kupić”, „nabyć na własność” 25 . W Nowym Testamencie pojawia się on tylko 4 razy (Ga 3, 13; 4, 5; Ef 5, 16; Kol 4,5) i również ma sens „kupienia", aczkolwiek w wypowiedziach apostoła nie ma żadnych podstaw do tego, by w ogóle się zastanawiać, komu i jaką cenę uiścił Zbawiciel, nabywając nas sobie na własność ${ }^{26}$. Czasownik ten raczej oznacza tu wyzwolenie ${ }^{27}$ i może przywoływać ideę z Wj 19, $5^{28}$, gdzie Bóg po wyprowadzeniu plemion izraelskich z niewoli egipskiej oświadcza, że odtąd będą jego własnością (hebr. segullāh) pod warunkiem jednak, że będą przestrzegać Jego przymierza (ideę tę przejmuje św. Paweł w Dz 20, 28, jak też 1 P 2, 9; Ap 5, 9). Paweł więc postrzega stan ludzkości obciążonej przekleństwem grzechu jako niewolę, z której Chrystus wyzwolił przez swą ofiarę złożoną na drzewie krzyża (zob. też Ga 4, 1-6) ${ }^{29}$.

Również w tym miejscu dochodzi do głosu paradoks krzyża polegający na tym, że to właśnie przeklęty staje się źródłem błogosławieństwa, które zostało obiecane Abrahamowi (por. Rdz 12,2-3), a teraz spływa na całą ludzkość (por. Ga 10, 14) ${ }^{30}$. Ten nieoczekiwany skutek poniżenia Jezusa

${ }^{25}$ Por. S. Lyonnet, L'emploi paulinien de eksagoradzein au sens de «redimere» est-il attesté dans la littérature grecque?, „Biblica” 42 (1962), s. 85-88.

${ }^{26}$ Tak uważają np. F. Büchsel, agoradzō, eksagoradzō, [w:] Theologisches Wörterbuch zum Neuen Testament, dz. cyt., s. 127; E. Szymanek, List do Galatów. Wstęp - przekład z oryginału - komentarz, Poznań-Warszawa 1978, s. 74 (Pismo Święte Nowego Testamentu, 6.2).

${ }^{27}$ Do takiego wniosku dochodzą np. F. Mußner, Der Galaterbrief, Freiburg-Basel-Wien 1974, s. 232; E. Szymanek, List do Galatów, dz. cyt., s. 74.

${ }^{28}$ Por. S. Lyonnet, L'emploi paulinien de eksagoradzein, art. cyt., s. 89.

${ }^{29}$ Por. F.-J. Ortkemper, Das Kreuz in der Verkündigung des Apostels Paulus. Dargestellt an den Texten der paulinischen Hauptbriefe, Stuttgart 1967, s. 12 (Stuttgarter Bibelstudien, 24).

${ }^{30}$ Por. G. Barbaglio, La legge mosaica nella Lettera ai Galati, [w:] La Parola di Dio cresceva (At 12, 24). Scritti in onore di Carlo Maria Martini nel suo $70^{\circ}$ compleanno, a cura di R. Fabris, 
Chrystusa staje się wymownym dowodem tego, że przepisy Prawa same w sobie nie mają mocy zbawczej oraz że usprawiedliwienie nie może być dziełem ludzkim. Odtąd zbawienie otrzymuje ten, kto zawierzył Zbawicielowi i poprzez wiarę włącza się w Jego ofiarę, która wyzwala grzesznika od ciążącego na nim piętna i przenosi ze śmierci do nowego życia.

Powszechne pojednanie jako cel ofiary

krzyżowej (Ef 2, 13-16 i Kol 1, 19-20)

Dalsze pogłębienie teologicznej refleksji nad rolą krzyża w zbawczym dziele Boga znajduje się w Ef 2, 13-16 i Kol 1, 19-20. Oba te teksty należą do listów, których autorstwo Pawłowe wciąż jeszcze jest dyskutowane wśród uczonych. Na podstawie szczegółowych badań ich stylu oraz porównania treści tych listów z listami powszechnie uznawanymi za Pawłowe można jednak przyjać, że nawet jeśli apostoł narodów nie jest bezpośrednim ich autorem, to ich redaktorzy musieli być jego uczniami i kontynuowali jego nauczanie w oparciu o jego poglądy. Godne uwagi jest jeszcze to, że listy do Efezjan i do Kolosan mają podobne słownictwo, styl, a nawet układ i treść całych bloków tekstu. Fakt ten może wskazywać na to, że u ich podłoża znajduje się jedna tradycja ${ }^{31}$. Podane wyżej fragmenty są częścią dłuższych tekstów poetyckich (Ef 2, 13-18; Kol 1,15-20), które najprawdopodobniej są dziełem Kościoła pierwotnego i były wykonywane jako hymny w czasie liturgii. Z chwilą jednak, gdy zostały przejęte przez samego Pawła albo jego uczniów, stały się integralnym elementem jego ewangelii o zbawczym dziele Chrystusa, a tym samym ważną częścią jego teologii.

Istniejący między tymi listami związek jest też widoczny we fragmentach Kol 1, 19-20 i Ef 2, 13-16. Najbardziej znamienne w nich jest to, że autor każdego z nich uznaje krew Chrystusa przelaną na krzyżu

Bologna 1998, s. 405; T. L. Donaldson, The 'curse of the Law' and the inclusion of the Gentiles, art. cyt., s. 105-107.

${ }^{31}$ Szerzej na temat relacji między obu listami zob. B. Adamczewski, List do Filemona. List do Kolosan. Wstęp - przekład z oryginału - komentarz, Częstochowa 2006, s. 135 (Nowy Komentarz Biblijny, 12); M. Zmuda, Kanoniczne relacje Listu do Kolosan i Listu do Efezjan, [w:] Wokół uniwersalizmu Pawła Apostoła. Materiały z sesji „Młodzi pytaja św. Pawła” 19 listopada 2008 r., red. nauk. R. Pindel, Kraków 2009, s. 59-69. 
za narzędzie pojednania oraz wprowadzenia w świecie pojednania i pokoju. W bardzo zwięzłym tekście Kol 1, 19-20 autor mówi o Chrystusie, że Bóg zechciał, ,aby w Nim zamieszkała cała Pełnia i aby przez Niego znów pojednać wszystko ze sobą: i to, co na ziemi, i to, co w niebiosach, wprowadziwszy pokój przez krew Jego krzyża". Na pierwszy plan wyłania się tu idea pojednania, która występuje też w Kol 1, 22 i Ef 2, 16. Autor wyraża ją czasownikiem apokatallassō, który chyba jest jego własnym tworem, gdyż nie występuje ani w Septuagincie, ani też w greckiej literaturze pozabiblijnej. Jest on rozbudowaną formą czasownika katallassō występującego w Rz 5, 10; 1 Kor 7, 11; 2 Kor 5, 18-20, który oznaczał pierwotnie czynność wymiany i w sensie metaforycznym może oznaczać zamianę wrogości w przyjaźń, a więc też pojednanie pojmowane w tekstach nowotestamentowych w kategoriach społecznych i teologicznych $^{32}$. W literaturze greckiej z pierwszych wieków po Chrystusie czasownik katallassō odnosi się głównie do zawierania pokoju po wojnie między zwaśnionymi narodami lub do naprawy stosunków między stroną pokrzywdzoną i winowajcą. Tam jednak inicjatywę pojednania musiała zawsze podjąć strona, na której ciążyła wina lub dług (podobnie jest też w 2 Mch 1, 5; 7, 33; 8, 29). W tekstach chrześcijańskich jest natomiast zupełnie inaczej, gdyż tu inicjatorem pojednania jest zawsze Bóg ${ }^{33}$. Autor Kol 1, 19 słowem eudokēsen („spodobało się Mu”, „zechciał”) daje do zrozumienia, że Bóg w swym Synu wypełnia dawne obietnice i w Nim podejmuje ostateczną inicjatywę pojednania ludzi ze sobą. W drugiej kolejności autor hymnu przedstawia środki i zasięg zbawczego dzieła Boga. Pierwszy środek ujmuje w słowach: „Zechciał bowiem Bóg, aby w Nim zamieszkała cała Pełnia" (Kol 1, 19). W zdaniu tym największym problemem jest właściwe rozumienie terminu to plērōma („pełnia”). Pomijając ożywioną dyskusję egzegetów na temat jego znaczenia ${ }^{34}$,

${ }^{32}$ Por. B. Adamczewski, List do Filemona. List do Kolosan, dz. cyt., s. 210.

${ }^{33}$ Por. J. Kręcidło, Pawłowa koncepcja pojednania człowieka z Bogiem w 2 Kor 5, 18-21, „Studia Theologica Varsaviensia” 45 (2007) nr 2, s. 35.

${ }^{34}$ Różne zdania uczonych na ten temat można znaleźć w opracowaniach takich jak: J. Łach, Tajemnica odkupienia i jej reperkusje $w$ życiu chrześcijanina $w$ świetle hymnu o pierwszeństwie Chrystusa (Kol 1, 15-20), [w:] Tajemnica odkupienia, red. L. Balter [i in.], Poznań 1997, s. 312 (Kolekcja Communio, 11); B. Adamczewski, List do Filemona. List do Kolosan, dz. cyt., s. 208-209; Ch. Stettler, Der Kolosserhymnus. Untersuchungen zu Form, traditionsgeschichtlichem Hintergrund und Aussage von Kol 1,15-20, Tübingen 2000, s. 152-153. 
można przyjąć wyjaśnienie podane przez B. Adamczewskiego, że słowo to zostało użyte w Kol 1, 19 w sensie ogólnym, który zakłada konkretyzację przez inny rzeczownik w dopełniaczu. Takie skonkretyzowanie jego sensu można znaleźć w Kol 2, 9, gdzie występuje wyrażenie:pan to plērōma tēs theotētos („cała pełnia bóstwa”). W tym kontekście określenie to oznacza duchowo-osobową obecność samego Boga, która w Chrystusie ujawniła się w całej swej pełni po Jego zmartwychwstaniu ${ }^{35}$. Z obecnością tą jest ściśle związana moc Boża, dzięki której Syn Boży zwyciężył śmierć i został wyniesiony do chwały Ojca. Ona też jest niezbędnym i skutecznym środkiem urzeczywistnienia zbawczego dzieła pojednania.

W Kol 1, 20 autor hymnu ukazuje jako narzędzie pojednania „krew Jego krzyża". W środowisku żydowskim takie wyrażenie ma szczególną wymowę $^{36}$, w krwi bowiem widziano pierwiastek życia (zob. Kpł 17, 11), którego dawcą jest Bóg. Z tego przekonania wyciągano wniosek, że krew stanowi wyłączną własność Boga i tylko Jemu może być ofiarowana. Ponieważ ten pierwiastek życia pochodzi od Boga, Żydzi uważali, że krew ma niezwykłą moc przebłagalną i oczyszczającą człowieka z win. Autor Kol 1, 20 stwierdza, że pojednanie dokonuje się poprzez wprowadzenie pokoju przez krew Chrystusa przelaną na krzyżu. Jak zauważa A. Jankowski, takie połączenie Bożego daru pokoju z krwią Chrystusa jako pośrednika nawiązuje do liturgii świątynnej, a szczególnie do Dnia Pojednania (jôm kippur) ${ }^{37}$. Liturgia sprawowana w tym dniu miała charakter pokutny, a jej celem było przebłaganie Boga za grzechy popełnione w ciągu roku. Żydzi wierzyli, że mocą krwi zwierząt ofiarnych, którą arcykapłan skrapiał przebłagalnię i którą nakładał na rogi ołtarza świątynnego, dokonuje się zadośćuczynienie za grzechy ludu oraz

${ }^{35}$ Por. B. Adamczewski, List do Filemona. List do Kolosan, dz. cyt., s. 209-210.

${ }^{36}$ Szerzej na ten temat zob. A. Penna, Il sangue nell'Antico Testamento, [w:] Sangue e antropologia biblica. Atti della settimana. Roma, 10-15 marzo, 1980, a cura di F. Vattioni, Roma 1981, s. 379-401; P. Sena, Pojęcie krwi w rozumieniu Starego Testamentu, [w:] Krew Nowego Przymierza. O biblijnej teologii Krwi Chrystusa, pod red. T. Chłopickiego, Częstochowa 1999, s. 10-22.

${ }^{37}$ Por. A. Jankowski, Listy więzienne świętego Pawła. Do Filipian - Do Kolosan - Do Filemona - Do Efezjan. Wstęp - przekład z oryginału - komentarz, Poznań 1962, s. 237 (Pismo Święte Nowego Testamentu, 8). 
oczyszczenie i uświęcenie ołtarza i świątyni (por. Kpł 16, 19. 30) ) $^{38}$. Idąc po linii tych przekonań, autor Kol 1, 20 wyznaje, że krew Syna Bożego złożona w ofierze na krzyżu ma moc przywrócić przyjazne relacje z Bogiem, które przez grzech zostały osłabione czy też wręcz zerwane.

Po ukazaniu środków pojednania autor hymnu stwierdza (w tekście greckim na samym końcu wersetu), że swym zasięgiem ogarnia ono „i to, co na ziemi, i to, co w niebiosach" (Kol 1, 20). Zdanie to Orygenes traktował jako podstawę swej koncepcji apokatastazy, czyli radykalnego pojednania z Bogiem wszystkich bez wyjątku stworzeń. Jednakże ściśle rzecz biorąc, tekst ten przedstawia nie tyle powszechne pojednanie z Bogiem całego wszechświata (świata ludzi i aniołów), ile Boży zamiar pojednania ze sobą wszystkich stworzeńn ${ }^{39}$. Autor tego zdania podobnie jak w Flp 2, 9-11 ustala ogólną zasadę pojednawczej działalności Boga, która ma rozmiary kosmiczne ${ }^{40}$. Jego wypowiedź jest swoistym wyznaniem wiary, w którym nie ma mowy o poszczególnych etapach jednania bytów ze Stwórcą. On akcentuje jedynie efekt końcowy całego procesu jednania, którym jest powszechny pokój oznaczający przeciwieństwo stanu zakłócenia i wrogości, harmonię przyszłego odnowionego wszechświata ${ }^{41}$. W tym sensie można uznać całą pieśń z Kol 1, 15-20 za hymn pochwalny na cześć zbawczego dzieła Boga dokonanego w Chrystusie ${ }^{42}$. „Kościół pierwotny, śpiewając ów hymn na terenach zagrożonych jakimś dziwnym oczekiwaniem działania różnych niebieskich mocy, otrzymuje wskazówkę, że jedynie Chrystus jest Tym, który potrafi wprowadzić we wszystkim ład i porządek" ${ }^{43}$.

${ }^{38}$ Por. S. Szymik, Żydowskie święta późniejsze, [w:] Życie religijne w Biblii, red. G. Witaszek, Lublin 1999, s. 335.

${ }^{39}$ Por. B. Adamczewski, List do Filemona. List do Kolosan, dz. cyt., s. 213. Różne sposoby interpretowania tej części hymnu przez egzegetów przytacza T. K. Abbott, A Critical and Exegetical Commentary on the Epistles to the Ephesians and the Colossians, Edinburgh 1991, s. 222-224.

${ }^{40}$ Por. S. E. Porter, Pokój, pojednanie, [w:] Słownik teologii św. Pawła, red. G. F. Hawthorne, R. P. Martin, D. G. Reid, red. nauk. wyd. pol. K. Bardski, Warszawa 2010, s. 607.

${ }^{41}$ Por. A. Jankowski, Rozwój chrystologii Nowego Testamentu, Kraków 2005, s. 81.

${ }^{42}$ Zob. Z. Kiernikowski, Hymn pochwalny dzieła Bogaw Chrystusie. Chrystus - Głowa Ciała (Kol 1, 12-23), [w:] Ad sapientiam cordis. Księga pamiatkowa dedykowana księdzu profesorowi Ludwikowi Gładyszewskiemu w 70. rocznicę urodzin, red. P. Podeszwa, W. Szczerbiński, Gniezno 2002, 299-322.

${ }^{43} \mathrm{~J}$. Łach, Tajemnica odkupienia i jej reperkusje w życiu chrześcijanina, art. cyt., s. 315. 
Podobną do Kol 1, 19-20 myśl, lecz w literackiej formie o wiele bardziej rozbudowaną, zawiera Ef 2,13-16. W Ef 2, 13 autor pisze, że ci, którzy niegdyś byli daleko od Boga, stali się Mu bliscy „przez krew Chrystusa”. To wyrażenie „przez krew Chrystusa” w podobnej postaci (,przez Jego krew”) znajduje się też w Rz 3, 25; 5, 9; Ef 1, 7; Kol 1, 20 (zob. też 1 Kor 11, 25) i bywa nazywane przez egzegetów utartą formułą soteryjną $a^{44}$. Autor przywołuje w niej przymierze synajskie, które zostało zawarte w krwi zwierząt ofiarnych (por. Wj 24, 5-8). Na mocy tamtego aktu Izrael, który niegdyś też był daleko od swego Pana, stał się Jego wyłączną własnością. Jezus Chrystus, oddając siebie w ofierze, ustanawia nowe przymierze, a Jego krew jako żertwa ekspiacyjna (por. $\mathrm{Hbr} 9,22)$ usuwa przeszkodę oddzielającą grzeszników od Boga ${ }^{45}$. Co więcej, staje się „naszym pokojem”. W tekstach biblijnych pokój należy do najważniejszych darów duchowych, których człowiekowi udziela Bóg nazywany wprost Bogiem pokoju (por. Sdz 6, 24). Jest synonimem dobrobytu, szczęścia, sprawiedliwości i zbawienia. Prorocy zapowiadali, że nastanie powszechnego pokoju w świecie nastąpi w czasach mesjańskich, a Mesjasza, który pojedna ze sobą zwaśnione narody, nazywali Księciem Pokoju (Iz 9, 5-6) lub wprost Pokojem (Mi 5, 4). Mówiąc zatem o Jezusie Chrystusie: „On jest naszym pokojem”, autor Ef 2, 14-16 wyraźnie nawiązuje do dawnych zapowiedzi prorockich i wyznaje, że ich wypełnienie dokonało się w Jego ofierze na krzyżu.

Wprowadzenie pokoju w praktyce oznacza wzajemne pojednanie dwóch rzeczywistości, które wcześniej były do siebie nastawione wrogo. O tym dziele autor Ef 2, 14-16 pisze, posługując się terminami bardzo ogólnymi: „On w swoim ciele z dwóch części uczynił jedno i obalił dzielący je mur wrogości. Uchylił Prawo przykazań zawartych w przepisach, aby z dwóch części stworzyć w sobie jednego nowego człowiekai wprowadzić pokój. On pojednał z Bogiem obie części w jednym ciele przez krzyż,

${ }^{44}$ Por. K. Romaniuk, „... gdy teraz przez Krew Jego zostaliśmy usprawiedliwieni” (Rz 5, 9), [w:] Krew Nowego Przymierza, dz. cyt., s. 132.

${ }^{45}$ Teologiczne znaczenie pojednania i pokoju w Ef 2, 13-16 omawia obszernie A. Suski, Tajemnica jedności Kościoła w świetle Ef 2, 11-22, „Studia Płockie” 11 (1983), s. 19nn; B. L. Melbourne, Ephesians 2 : 13-16: Are the Barriers Still Broken Down?, „The Journal of Religious Thought" 58 (2005) nr 1-2, s. 107-119; J. P. Heil, Ephesians. Empowerment to Walk in Love for the Unity of All in Christ, Atlanta 2007, s. 122 nn. 
zabijając w nim tę wrogość" ${ }^{4}$. Pojednanie ze sobą dwóch zwaśnionych stron może dojść do skutku tylko wtedy, gdy zniknie prawdziwa przyczyna podziału lub niezgody. O jej usunięciu autor mówi w obrazowy sposób: to mesotoichon tou fragmou lysas (,po obaleniu dzielącego je muru wrogości"). Rzeczownik to mesotoichon oznacza mur środkowy oddzielający od siebie dwie części budowli, zaś ho fragmos - płot, ścianę lub palisadę. Cały zwrot zatem wyraża ideę usunięcia muru granicznego, który jak ściana nie do przebycia oddzielał od siebie dwie części, które ze swej istoty powinny być jednością. Niektórzy egzegeci uważają, że w tekście tym chodzi o brak przyjaźni między Bogiem a ludźmi ${ }^{47}$ albo o przedział kosmiczny oddzielający ziemię od sfery nadprzyrodzonej ${ }^{48}$. Większość egzegetów jednak twierdzi, że obraz ten odnosi się do muru kamiennego, który w świątyni jerozolimskiej oddzielał dziedziniec pogan od dziedzińca Izraela ${ }^{49}$. Według Józefa Flawiusza, nad bramą tego muru widniał napis, który zabraniał poganom pod karą śmierci wstępu na dziedziniec wewnętrzny ${ }^{50}$. W oczach Żydów mur ten symbolizował oddzielenie narodu wybranego od całego świata pogańskiego, które zostało anulowane przez śmierć Chrystusa.

Takie wyjaśnienie, choć jest bardzo przekonujące, opiera się jednak tylko na ogólnym skojarzeniu tekstu Ef 2, 14 z murem świątynnym. W rzeczywistości jednak w tekstach starożytnych mur ten nie był określany terminem mesotoichon, a w świątyniach Azji Mniejszej w ogóle nie istniała podobna przegroda, z czego wypływa wniosek, że aluzja taka nie mogła być zrozumiała dla adresatów Listu do Efezjan. Ponadto Ef 2, 21 wskazuje na to, że w całym fragmencie Ef 2, 13-21 jest aluzja nie

${ }^{46}$ Cyt. za: Pismo Święte Starego i Nowego Testamentu. Najnowszy przekład z języków oryginalnych z komentarzem, opracowane przez zespół biblistów polskich z inicjatywy Towarzystwa Świętego Pawła, Częstochowa 2005.

${ }^{47}$ Por. np. C. Schneider, Mesotoichon, [w:] Theologisches Wörterbuch zum Neuen Testament, in Verbindung mit zahlreichen Fachgenossen hrsg. von G. Kittel, t. 4, Stuttgart 1942, s. 629.

${ }^{48}$ Tak uważali np. H. Schlier, Christus und die Kirche im Epheserbrief, Tübingen 1930, s. 18-26; A. Lindeman, Die Aufhebung der Zeit. Geschichtsverständnis und Eschatologie im Epheserbrief, Gütersloh 1975, s. 161-166.

${ }^{49}$ Tak twierdzą np. T. K. Abbott, M. Barth, J. S. Huby, A. Jankowski, W. Lock, F. Mussner, J. A. Robinson, E. F. Scott i inni; por. A. Suski, Tajemnicajedności Kościoła w świetle Ef2,11-22, art. cyt., s. 22, przyp. 49. Autor artykułu również opowiada się za tym wyjaśnieniem.

${ }^{50}$ Por. Józef Flawiusz, Dawne dzieje Izraela, XV, 11, 5. 
do świątyni materialnej, lecz duchowej ${ }^{51}$. Z tych względów będzie zapewne rzeczą najprostszą stwierdzić, że autor poetyckiego tekstu Ef 2 , 14 nie czyni aluzji do jakiejś konkretnej rzeczywistości, ale posługuje się zwyczajną metaforą, która wyraża brak jedności zarówno w świecie ludzi, jak też między ludźmi a Bogiem. Nieprzyjaźń ta podobnie jak mur jest tak trudna do pokonania, że wymaga nadprzyrodzonej interwencji. To Boże dzieło - podobnie jak krzyż - ma dwa wymiary: horyzontalny, w którym dokonuje się wzajemne pojednanie zarówno poszczególnych ludzi, jak też całych narodów, w tym także pojednanie Żydów i pogan, oraz wertykalny, w którym dochodzi do pojednania między Bogiem a ludzkością (por. Rz 5, 10) 52 $^{2}$. Doprowadzenie do skutku tego dzieła wymagało równego traktowania wszystkich ludzi i narodów, dlatego jego konsekwencją jest zniesienie separatystycznego prawodawstwa żydowskiego, aby starotestamentowe obietnice mogły się spełnić także wśród pogan i by zbawienie mogło uzyskać charakter uniwersalny ${ }^{53}$. W stwierdzeniu tym nie chodzi o to, że Prawo Boże dane przez Mojżesza zupełnie przestało obowiązywać. Wątpliwości te rozwiewa sam Jezus w Mt 5, 17, gdzie oznajmia, że Jego zadaniem nie jest anulowanie dawnych przepisów prawnych, lecz ich udoskonalenie. Idąc po tej linii, odrzucił On błędne interpretacje Bożego Prawa, a następnie wszystkie przykazania sprowadził do przykazania miłości (por. Mt 22, 36-40), w którym również wyodrębnił wymiar wertykalny (miłość Boga) i horyzontalny (miłość bliźniego). W kontekście Jego wypowiedzi ewangelicznych można uznać, że tym, co definitywnie niszczy wszelkie podziały i doprowadza do jedności dwie strony nastawione do siebie nieprzyjaźnie, jest miłość wzorowana na miłości samego Zbawiciela.

Autor hymnu kończy swą refleksję stwierdzeniem, że Chrystus dokonał pojednania „w jednym ciele przez krzyż, zabijając w nim tę wrogość" (Ef 2, 16). Wyrażenie „w jednym ciele” jest dwuznaczne. W kontekście całego hymnu może się odnosić zarówno do ukrzyżowanego ciała

${ }^{51}$ Te i inne zastrzeżenia podnosi w swym komentarzu E. Best, A Critical and Exegetical Commentary on Ephesians, Edinburgh 2001, s. 254.

${ }^{52}$ Por. tamże, s. 258.

${ }^{53}$ Por. A. Suski, Tajemnica jedności Kościoła w świetle Ef 2, 11-22, art. cyt., s. 23; H. Langkammer, Hymny chrystologiczne Nowego Testamentu. Najstarszy obraz Chrystusa, Katowice 1976, s. 111. 
Chrystusa, jak też do Kościoła, który jednoczy w sobie Żydów i pogan. Jest rzeczą możliwą, że autor celowo zamierzył „dwupiętrowość” terminu „,ciało” ${ }^{54}$, by w ofiarę Zbawiciela na krzyżu włączyć także Kościół stanowiący mistyczne ciało Chrystusa, albo że użył takiego wyrażenia, by przeciwstawić się poglądom doketów ${ }^{55}$, którzy odrzucali możliwość fizycznej śmierci Chrystusa. Choć sam ten fragment nie jest do końca jasny, teologiczna interpretacja całego hymnu z Ef 2, 13-16 nie nastręcza większych trudności. Autor bowiem wyraźnie w nim podkreśla, że krzyż Chrystusa stał się narzędziem pokonania zarówno podziałów w świecie ludzi, jak też nieprzyjaźni między ludźmi a Bogiem. To dzieło pojednania mogło dojść do skutku tylko dlatego, że w ofierze Syna Bożego ujawniła się wielka miłość do człowieka oraz moc, która jest w stanie zniszczyć wszelkie zło będące źródłem wrogości w świecie ludzi.

Warszawa

FRANCISZEK MICKIEWICZ SAC

\section{Słowa kluczowe}

Krzyż, krew Chrystusa, ofiara na krzyżu, miłość Chrystusa, pojednanie

\section{Summary}

The role of the cross in the saving work of God in the theology of St. Paul

The author of this article analyzes the texts, in which St. Paul writes on the subject of Christ's sacrifice on the cross. In Ga 2: 19-20 the apostle presents the love of Christ as an essential feature of his nature and he suggests that this love was expressed in the particular, historical self offering on the cross. In Rom 5: 7-8 he states that the only motive for the redeeming sacrifice, which the Son of God offered of himself, following the will of the Father, is the heroic love, shown in the death for sinners. Despite the fact that in the antiquity the cross was a tool of the most degrading and humiliating death, St. Paul writes in Ga 6:14 that he boasts of the cross of Jesus Christ, furthermore, in 1 Cor 1: 24 he adds that the crucified Christ is "the power of God and the wisdom of God". In Ga 3: 13 Paul observes a state of humanity, overloaded with the curse of sin, as a slavery, from which the Christ freed it, through his sacrifice offered on the wood of the cross, because on it, by his own will he took this curse, which was leading human-

${ }^{54}$ Por. A. Suski, Tajemnica jedności Kościoła w świetle Ef 2, 11-22, art. cyt., s. 26.

${ }^{55}$ Między innymi takie przypuszczenia snuje E. Best, A Critical and Exegetical Commentary on Ephesians, dz. cyt., s. 259. 
ity to condemnation, on himself. Further deepening of the theological reflection on the role of the cross in the saving work of God can be found in Eph 2:13-16 and Col 1: 19-20. The author of these texts recognizes the blood of Christ, poured out on the cross, as the tool of reconciliation and introducing peace and reconciliation to the world.

\section{Keywords}

The cross, the blood of Christ, Christ's sacrifice on the cross, the love of Christ, the reconciliation 